Have you more property at your command than he has?

Or can you make more judicious purchases?

Can you boast more powerful friends or wealthy connections?

Are you more persevering than the Gillmores?

Have you more honesty and integrity than Pool?

Have you more cuning and craft than Willis?

Are you a better Republican than Wheelock?

To sum up the whole are your quallifications collectively considered any better for Trade in this Town than what is common to those I have named? Are your means to commence and carry on trade trully and simply considered any better than theirs? And will not twelve per cent for Money opperate in the end (like that Creature who is said to eat through the bowels of its Dam) and finally be the means of impoverishing your Father? I know that the above are home questions, but you will consider that they are asked by a Friend and dictated by a Brother and pardon such as may be amiss

I am sir etc.

Dr. Howard

Mr. E. Howard Jr. I do not wish that you should suppose from anything I have wrote that I am one of those that raise an expectation in another \& then feast myself with their disappointment - no I detest such conduct - I have at present no notion of receding from what I have said but have wrote merely to show you the possibility of your calculation being much too favorable - It will not do for me tn build too many Castels in the air

\title{
An Inventory of Business Records
}

A small book, recently come to the editor's desk, merits attention. It is entitled Inventory of Business Records: The D. Connelly Boiler Company, The J. B. Savage Company'. It shows that important work is being done in preserving business records in the city of Cleveland. The Foreword attributes the beginning of this work to the late Professor Robert C. Binkley of Western Reserve University, who was untiring in his effort to persuade owners to preserve their records or to turn them over to some

1Prepared and published in May, 1941, by the Ohio Historical Records Survey, Work Projects Administration, Cleveland, Ohio. 
depository and who conveyed to his students and others some of his appreciation of the value of business records.

As the Preface states, this publication is an experiment in the field of business archives. Of the 104 pages about one-half are devoted to each of the two companies the names of which appear in the title. A short historical sketch is given for each company; in the "Inventory of Records" for each company the different kinds or series of records are carefully discussed as to amount, years covered, and content; and, for the Connelly Company papers, a calendar of letters is given which clearly illustrates the content and value of the correspondence. 